\title{
Folmer Christiansen's erindringer fra Højer
}

Disse erindringer er en afskrift af et video-interview med Folmer Christiansen, som blev foretaget i efteråret 2007. Interviewet kan ses på websiden unvw.vimu.info, men vi har også valgt at bringe interviewet i Sønderjyske Arbøger. Der er tale om et mundtligt interview, der har karakter af at være et foredrag med meget få afsluttende spørgsmål, og selv om Folmer Christiansen var meget præcis i sine formuleringer, er der forskel på talesprog og skriftsprog. Derfor har vi foretaget nogle få sproglige korrektioner for at præesentere erindringerne så læsevenligt som muligt. Men redaktionen er sket under den klare forudsætning, at det er Folmer Christiansens budskaber, der videregives, og vi har ikke ændret $\mathrm{i}$ den opbygning, som Folmer Christiansen fulgte i foredraget. Enkelte steder har vi indsat forklarende noter.

\section{Forord $^{1}$}

Folmer Christiansen blev født den 2. juli 1913. Han var uddannet lærer fra Silkeborg Seminarium og betegnede sig selv som en "Nørresundbydreng «. Hans forældre - Christine og Jens Christiansen - var henholdsvis syerske og træskomager. Han tog først en præliminæreksamen og dernæst en lærereksamen, inden han i 1936 blev ansat som lærer Rens. Under sit ophold i Rens blev han gift med Bodil, som var gårdmandsdatter fra Ubby på Sjælland, og ingen af de to havde således nogen direkte familiemæssig relation til Sønderjylland. I april 1939 flyttede Folmer Christiansen til Højer, hvor han blev ansat som andenlærer på den danske skole i byen. Frem til sin død den 3 . februar 2011 havde han meget stor betydning for byen, først og fremmest som lærer og skoleinspektør i Højer gennem et halvt århundrede. Han var samtidig meget aktiv i mange andre sammenhænge blandt andet som medlem af byrådet, som formand for ungdoms- og idrætsforeningen og som medlem af bestyrelsen i Tønder Amts Idrætsforening. Han og hans hustru var desuden som grundtvigianere stærkt involveret i forskelligt kirkeligt arbejde.

Efter sin pensionering engagerede han sig stærkt i Lokalhistorisk Arkiv, han skrev flere lokalhistoriske bøger, og han holdt talrige foredrag. Han var kort sagt meget engageret og havde et stort kontaktnet - især i den vestlige del af Sønderjylland, men også i andre dele af Danmark. Han var ubetinget dansk, men det danske var for ham 
lig med åbenhed og respekt for andre. Derfor havde han - som det også fremgår af erindringerne - et nært forhold til sine tysksindede naboer.

Folmer Christiansens erindringer kan ses i sammenhæng med Poul Andersens erindringer, som blev udgivet i Sønderjyske Arbøger i 1978 under overskriften »Mine 9 år i Højer«. Andersen kom til Højer i februar 1935, hvor han købte gården Søgård, inden han i 1944 flyttede fra byen, da han overtog en gård ved Visby.

\section{Folmer Christiansen fortæller}

Jeg kom til Sønderjylland fra Nørresundby. Jeg var i 1935-36 realskolelærer i Nørresundby, men jeg havde fået den idé, at jeg absolut ville prøve at undervise $i$ en landsbyskole. Først søgte jeg otte andenlærerstillinger, blandt andet den i Rens. Da jeg fik sommerferie cyklede jeg til Rens, idet jeg ikke havde hørt noget derfra. Jeg kom dertil en søndag, og gik ind på den tyske kro - jeg vidste ikke, at den var tysk og spurgte, om jeg kunne få middagsmad. Jeg fik frikassé sammen med familien, der sad i skænkestuen. Derefter gik jeg ned på skolen for at hilse på førstelæreren, men jeg fik at vide, at han var i kirke $i$ Burkal, og så cyklede jeg tilbage til Burkal. Det var midt i kirketiden, så jeg gik i stedet ind på Saksborg Kro, som var det tyske samlingssted på egnen. Det vidste jeg ikke noget om. Der sad to mænd derinde, og de bød meget gemytligt velkommen. "Værsgo at sætte dig ned, her er god plads«. Jo tak, sagde jeg og bestilte en øl og sad og hørte på dem. De talte skiftevis sønderjysk og tysk. Det havde jeg aldrig været ude for før, så jeg var vældig interesseret. Ikke mindst da de begyndte at fortælle om den lærerstilling, jeg havde søgt i Rens: hvorfor kunne de ikke tage den vikar, de havde, $\mathrm{i}$ stedet for at hente en mand oppe fra Århus eller Ålborg? De blev ved at sidde og skælde ud på den her mand fra Århus eller Ålborg. Det var det første, jeg fik at vide om, at jeg var indstillet til stillingen.

Jeg traf førstelæreren efter kirketiden. Han sagde, at de havde haft de oplysninger, de havde brug for, og havde således ikke behøvet at sende bud efter mig. Derfor blev jeg ansat som andenlærer i Rens og var der i tre år. I Rens var der tysk og dansk skole i samme bygning: tysk skole i den vestlige ende og dansk skole i den østlige ende. Andenlærerboligen var ovenpå. Den tyske førstelærerbolig var i en udbygning mod vest, og den danske førstelærerbolig i en udbygning 


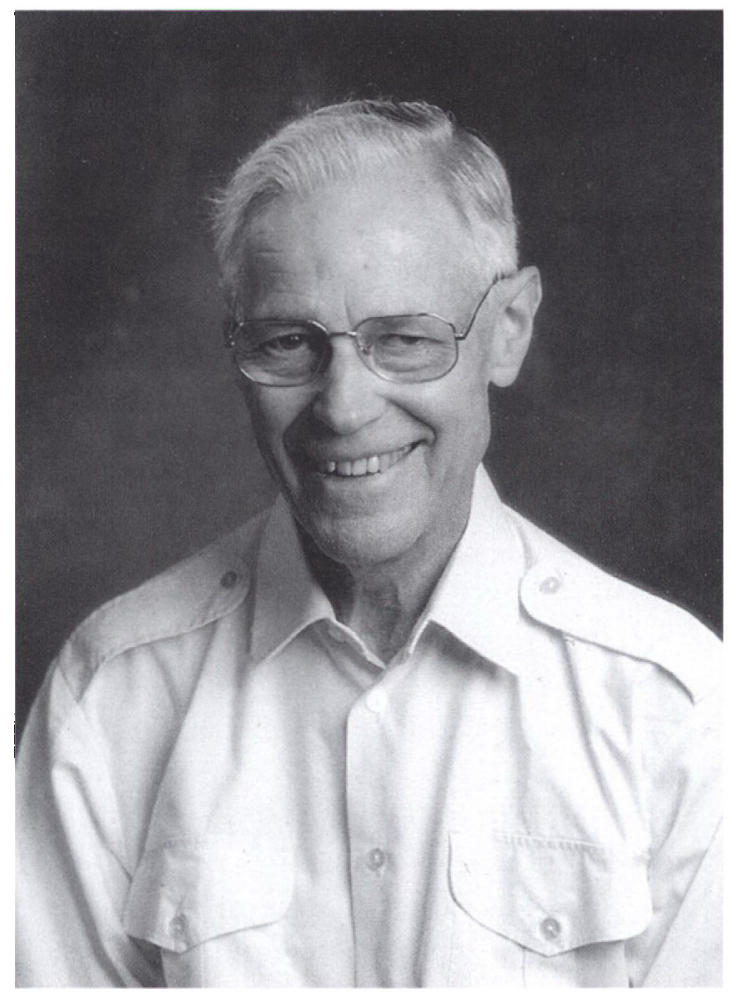

Folmer Christiansen. Fodt den 2. juli 1913, død den 3. februar 2011. Disse erindringer er baseret på et videointerview, der fandt sted i efteråret 2007, og som kan ses på www.vimu.info.

mod øst. Den tyske førstelærer var gift med en pige fra Frederiksberg, og den danske førstelærer var gift med en datter af den tidligere tyske lærer i Rens.

Jeg vidste intet om dagligdagen i grænselandet, men jeg havde haft historielærere, der var meget interesseret i sønderjyske forhold. Derfor var jeg ret velbevandret i Sønderjyllands historie. Efter tre år i Rens, hvor jeg blev gift - min kone var sjællænder - blev vi i 1939 opfordret til at søge andenlærerstillingen i Højer, hvortil vi kom den 4. april 1939. Det var dagen efter det valg, hvor tyskerne i Sønderjylland gik til valg under parolen: "Ein Reich, ein Volk, ein Führer«. Det var jo rene ord for pengene.

Det var jo sådan i Højer, at de fleste af de voksne mænd havde været indkaldt som soldater under Første Verdenskrig, og 51 fra 
Højer og Højer Landsogn var faldet. I november 1918 kom våbenstilstanden, og så udbrød der revolution rundt om i Tyskland, og der blev dannet arbejder- og soldaterråd. Det skulle man også have i Højer, og det foregik på den måde, at man sendte den offentlige udråber ud med sin tromme og bekendtgjorde: »I morn klok tolv æ dæ revolution o æ mærkensplads. Ål minneske ska hold sæ in, å ål vinner ska væ låt.« Næste dag samledes naturligvis hele byens befolkning på torvet, og det landstormskompagni, som var stationeret der, marcherede ind på torvet klokken 12 og stillede op med kaptajnen foran. Præcis klokken 12 kom der en lille afdeling marinere fra Flensborg og marcherede ind på pladsen. Lederen af marinerne gik lige hen til kaptajnen for landstormen og hev hans epauletter ${ }^{2}$ af og tog hans sabel fra ham. Dermed var revolutionen i Højer forbi. Derefter skulle der dannes arbejder- og soldaterråd. Det foregik om aftenen på Centralhotellet, og det var igen denne mariner fra Flensborg, der førte ordet. Han var godt kendt med forholdene i Højer - måske har han været fra Højer, det ved jeg ikke - og han foreslog en bestemt håndværker til formand for arbejder- og soldaterrådet, men håndværkeren svarede: »Næj, de kan æ it, det stemme it mæ mi kristne overbevisnen," hvortil marineren svarede: "de æ jævn så'n jen, vorherre væl ha." Så det var ikke let at komme udenom, men det blev nu ikke ham, der blev formand for arbejder- og soldaterrådet, og det fik nok ikke større betydning i Højer.

Det var på baggrund af Versailles-freden, at det var bestemt, at der skulle være folkeafstemning i Sønderjylland for at afgøre, om Sønderjylland skulle til Danmark eller til Tyskland. Sønderjylland blev delt i tre zoner; den første zone gik fra Kongeåen, hvor grænsen gik i den tyske tid, og ned til den nuværende grænse, og der stemte man den 10. februar 1920. Det viste sig, at der i hele området var $75 \%$ danske stemmer, og derfor kom hele dette område med til Danmark til trods for, at der var enkelte sogne, hvor der var tysk flertal. Det var der blandt andet i Højer, og der var et stort tysk flertal på ca. $73 \%$ tyske og kun de her $27-28 \%$ danske stemmer. Man kan godt forstå, at tyskerne i Højer var meget fornærmede over, at de ikke kom med til Tyskland. Jeg har altid haft den anskuelse, at det med Genforeningen var retfærdigheden, der skete fyldest, men jeg kan godt se, at for tyskerne, der nu skulle til at være danske sønderjyder, var det anderledes. En gammel tysker skrev i sin bibel: »Min Gud, min Gud, hvorfor har du forladt os? Hvor kan det være din mening, at vi trofaste 
tyskere nu skal gøres til sønderjyder sammen med de hadefulde jyder? Gud hjælp os i vor nød." Det var ganske ærligt ment fra hans side, men han har aldrig haft en tanke for, hvad danskerne måtte gennemgå i tyskertiden fra 1864 til 1920.

Efter Genforeningen skulle man jo prøve at leve sammen med hinanden under de forandringer, som det jo gav, at landet kom ind under dansk lovgivning. Men danskere og tyskere i Højer havde jo levet sammen i mange, mange år og egentlig altid haft et forholdsvis godt naboskab. De fandt hurtigt ud af at leve sammen på en ordentlig måde. Det var sådan i 20'erne, at de unge danske gendarmer godt kunne spille fodbold sammen med tyske unge. Det blev anderledes, da nazismen kom i 1933.

Som sagt; vi kom til Højer i 1939, og det var jo, da nazismen var på sit højeste. I Højer var de allerfleste tyskere simpelthen gået over til nazismen. Det påvirkede naturligvis hele forholdet mellem dansk og tysk, og der blev en stærkere spænding, end der havde været før. Alligevel bevaredes de gode naboforhold stort set gennem nazitiden og selv gennem besættelsestiden. Jeg er ikke helt enig med alle mine danske venner om det, men det er altså mit indtryk, at det gode naboskab blev bevaret. Det var jo sådan i Højer, at alle kendte alle. I skolen skulle vi jo sørge for at sælge forårsmærker og Dybbøl-mærker, og hvad der ellers var af den slags ting. Når det havde sociale formål kunne man sige til dem, der skulle gå rundt med mærker: »I kan roligt gå ind til alle steder.« Hvis det var Dybbøl-mærker, så fik de at vide: "I skal kun gå ind til danskere." Når jeg sendte Bothilde ${ }^{3}$ af sted, var jeg sikker på, at hun kom ind til alle danske og ingen tyske. Da der så i skolen kom flere børn udefra, kunne det jo godt være, at de kom ind det forkerte sted, når de var ude med Dybbøl-mærker. De fleste tyske tog det meget large og sagde: »Det skal du et andet sted hen med, « men der var også nogle steder, de fik et møgfald, og så gik de jo ikke med mærker igen.

Det er jo nemt at forstå, at der var $73 \%$ tyske og $27 \%$ danske stemmer i Højer, men forholdet var meget mere indviklet end som så. Troels Fink ${ }^{4}$ har engang, han var i Højer, sagt: "I Højer er der fem slags mennesker. For det første de danske, for det femte de tyske, og så er der midtimellem dem man kalder 'blakkede',." Det siger man selvfølgelig ikke til dem selv. Altså dem, der hverken føler sig danske eller tyske, men er sådan midtimellem. Måske stemmer de ved et valg dansk og ved et andet tysk. Den elskværdige sognepræst i Højer, 
N.P. Nielsen, kaldte dem 'de uafgjorte'. Kategori nummer to var de blakkede, der hældte til dansk side, og nummer fire de blakkede, der hældte til tysk side. Sådan sagde Troels Fink. Det lyder indviklet, men i praksis vidste vi omtrent, hvor vi skulle anbringe de forskellige mennesker i de fem grupper.

Jeg har selv fundet ud af, at der var en sjette gruppe; det var Jyllands-tyskere. Altså folk, der kom nordfra til Sønderjylland og ikke kunne være andet end danske, men som så gik over til tyskheden - i regelen fordi de blev tysk gift. De blandede ægteskaber - som der jo har været en hel del af - fungerede normalt på den måde, at når det var en dansk pige og en tysk mand, så gik hun over til tyskheden. De fleste af de blandede ægteskaber blev tyske, men der var en håndværker herfra, som var på valsen i Nordsjælland og fandt en pige deroppe, og de blev gift og flyttede til Højer. Han var alle dage tysk, og hun var alle dage dansk, og det var der ingen, der tog anstød af. Der var en enkelt familie - det var en mejeribestyrer - han blev tysk gift og fik tre sønner, hvoraf de to blev danske og den tredje tysk. En af de danske blev gift med en pige nordfra, og hun havde det ikke ret godt med, at der var det skel mellem dansk og tysk, og havde det ikke ret godt med, at der også var tyskhed i familien. Samtidig havde hun og hendes mand et meget nært venskab med en tysk snedkermester i Højer.

Højer er karakteristisk ved, at danske og tyske bor imellem hinanden. I samme hus kan der bo en dansk familie og en tysk familie, og er der sygdom i den ene familie, ja så hjælper man fra den anden. Er der dødsfald går man til begravelse uanset, om det er en dansk eller tysk. Jeg kan nævne en enkelt begravelse; det var en håndværker, der døde i 50'erne, og han var 'blakket' - jeg tror med hældning til dansk side - men hans kone var tysk. Vi regnede alle sammen med, at det skulle være en tysk begravelse, men efter dødsfaldet kom enken op til den danske præst og spurgte, om han ville påtage sig begravelsen. Det sagde han naturligvis ja til. Om han havde noget imod, at den tyske præst holdt en andagt $i$ hjemmet inden højtideligheden i kirken; nej det havde han ikke noget imod. Så var der andagt i hjemmet, mens vi stod nede på gaden. Jeg har i 35 år gjort tjeneste som degn ved danske gudstjenester og kirkelige begivenheder; så vi stod og ventede. Derefter blev kisten ført ned i kirken, hvor den danske præst tog over, og vi sang danske salmer. Ude på kirkegården overtog den tyske præst bestillingen, og vi sang en tysk salme. 
Bagefter var der en sammenkomst på Hotel Sylt, og der talte først den tyske præst, tysk salme, og så den danske præst, dansk salme. Der var nok nogen, som syntes, at det var temmelig broget, men det var altså bare sådan, som forholdene kan være i Højer.

Højer var i mange år afhængig af Sonderjysk Tæppefabrik. Den blev startet af en fynbo i 1919. Han havde studeret tekstilvirksomhed i Tyskland, og der havde han fundet sin kone i Hannover, hvorfor hun flyttede med til Danmark. Hun valgte at følge sin mand, og jeg synes, det lykkedes hende helt godt at komme ind i det danske. Han købte i 1919 et lille uldspinderi, der beskæftigede fire mennesker. Der var den klausul i handlen, at hvis Højer kom til Tyskland, skulle handlen gå tilbage. Han ville have sin virksomhed i Danmark. Han gav sig til at fremstille tæpper og drev den op til i 40'erne at være Tønder Amts største industrivirksomhed. Hans søn - som overtog fabrikken efter ham - giftede sig med datteren af byens tidligere tyske borgmester, og hans søn igen - der også har været direktør på tæppefabrikken - giftede sig med datteren af den tyske præst her. Det var altså tredje generation af sådan et blandet ægteskab. Når man spurgte nummer to Kjærby ${ }^{5}$ - og det var der somme tider nogen, der gjorde hvordan klarer I jer egentlig i Højer med alle de tyskere, så svarede han: "Vi gifter dem ihjel.“

Jeg kender i øvrigt forholdet fra min egen familie. Vi havde en skrigende dreng i barnevognen med, da vi flyttede til Højer, og hvis nogen dengang midt i nazitiden havde sagt, at han en dag skulle gifte sig med en pige fra et tysk hjem, så tror jeg, at vi havde været meget betænkelige ved at flytte til Højer. Det blev han imidlertid, og bedre svigerdatter har ingen fået. Jeg kan lige sige, at min søn, der blev gift med en pige fra et tysk hjem, blev lærer i Felsted, og det blev hans kone også. Der gik det sådan, at deres ældste datter forelskede sig i en ung tysker fra byen, og de blev gift. Det er derfor anden generation af et blandet ægteskab. De bor nu i Nordsjælland", så der er ikke nogen problemer.

Vi havde $\mathrm{i}$ en del år en meget dygtig historielærer, Mollerup, på skolen i Højer. Han giftede sig med en tysk pige fra Højer. Hele hendes familie og omgangskreds var tysk, og det bevirkede, at de efterhånden syntes, det var for vanskeligt at blive i Højer. Derfor flyttede de til Rudkøbing, hvor de stadig bor, men det halve af hans hjerte hænger stadigvæk ved Højer.

Efterhånden har man jo fundet ud af, hvem der var danske, og 


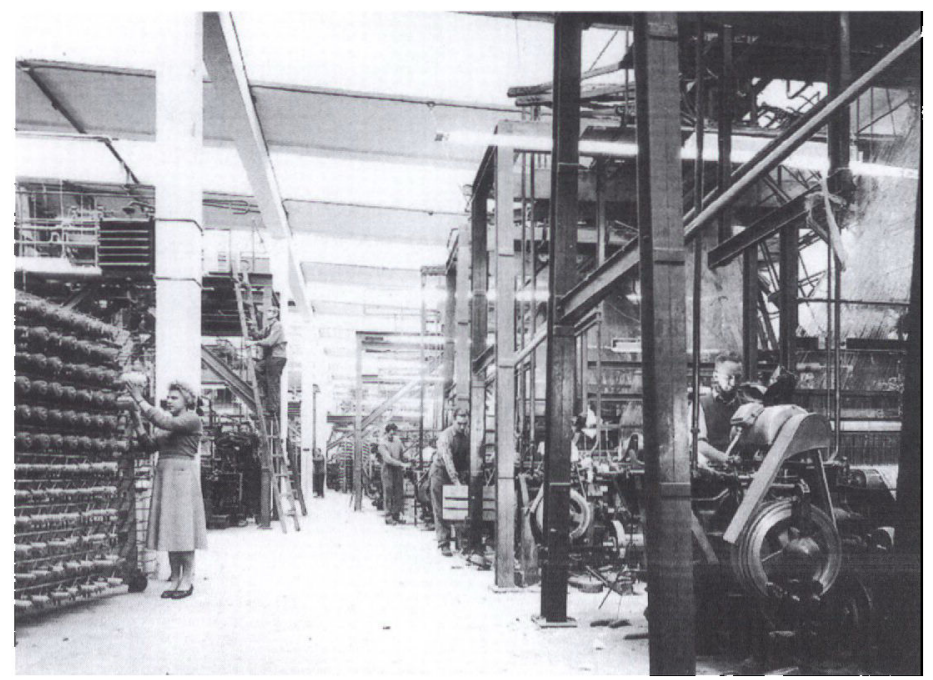

Væveriet på Sønderjysk Tæppefabrik $i$ Hojer, ca. 1960. Sonderjysk Tæppefabrik $i$ Højer var i 1940'erne den største industriarbejdsplads $i$ Tonder Amt. Familien Kjærby ejede og ledede fabrikken $i$ flere generationer. Både Kjarby-familien og Folmer Christiansens egen familie er kendetegnet ved, at der har varet flere blandede dansktyske ægteskaber.

hvem der var tyske, og som jeg sagde for, så kendte alle i byen hinanden før og under krigen. Men indtil for få år siden har jeg stadigvæk kunnet komme ud for overraskelser med hensyn til, om begge ægtefæller enten var tyske eller danske. Jeg kan lige fortælle en lille historie om det. Der var en tysker i byen, som fik en dansk kone, og hun valgte at følge sin mand. De fik to døtre, der begge kom i tysk skole. Jeg har altid anset hele familien for at være tysk. Men under krigen skete der det, at der blev afholdt en tysk børnefest. Pigerne skulle naturligvis med til den tyske børnefest - den begyndte om formiddagen - men før de gik til festen, sagde moren til dem: "I skal være hjemme klokken halvtolv. « Jamen, det er jo midt under festen, sagde de, det kan vi da ikke. "I skal være hjemme klokken halvtolv og ikke et minut senere. « Det måtte de jo så rette sig efter. De kom hjem klokken halvtolv, og da de kom ind, låste moren døren. Der var en trykket stemning ved middagsbordet, og pigerne spurgte, hvad der var i vejen. Det kunne de ikke få noget at vide om, men senere viste det sig, at der gik det rygte, at eleverne i den tyske skole klokken tolv skulle sværge ed til hagekorsflaget. Det skulle hendes piger i 
hvert fald ikke. Da middagen var forbi, og klokken var blevet halv et, fik de lov til at gå til festen igen. Det var ikke rart for konen - og i øvrigt heller ikke for manden - at den tyske forening forærede dem et tysk hagekorsflag. Under krigen var det sådan, at vi godt vidste, at der rundt i de tyske kommodeskuffer lå hagekorsflag. Der var også nogle tyskere, der allerede havde hejst flagstangen, men der kom nu aldrig hagekorsflag op i dem. Det endte med, at moren farvede hagekorsflaget mørkerødt og syede en nederdel til et af børnene af det.

Det var sådan, at i den tyske tid fra 1864 til 1920 var der kun tysk skole i Højer. I oktober 1920 blev der oprettet en dansk skole, og så skulle den jo have lokaler at være i. Det sparsommelige byråd fandt ud af, at alle børnene hidtil havde kunnet få plads i den forholdsvis nye skolebygning fra 1905, og det måtte de også kunne i fremtiden. Det blev sådan, at den danske skole fik to klasser i den nordlige del, og den tyske skole fik tre klasser i den sydlige del. Over indgangsdøren stod der "Lasse die Kindheit zu mir kommen «, og op ad trapperne stod der også tyske indskrifter. De var nu meget uskyldige, og det kunne ingen have noget imod. Men vi mente alligevel, at nu var vi jo i Danmark, og hver gang der skulle males, blev de tyske indskrifter malet over.

$\mathrm{Da}$ den danske kvindelige undervisningsminister, Nina Bang7, første gang var i Højer, havde hun fået noget at vide i forvejen. Blandt andet at lærerværelset var fælles for danske og tyske lærere, og at der stadig hang et billede af Kejser Wilhelm. Da hun kom ind i lærerværelset sammen med lærerne og skolekommissionen, pegede hun på billedet og sagde: »Hvem er det?«. Ja, det er jo der Kaiser. »Vi har ingen kejser - det skal væk.« Derfor måtte de jo have kejseren væk, hvorefter lærerne $\mathrm{i}$ fællesskab bestemte tre billeder til at hænge på væggen i stedet for. Danskerne valgte Brorson, og tyskerne valgte Goethe, og i fællesskab tog de den schweiziske pædagog, Pestalozzi. Sådan var der på lærerværelset, da jeg kom til. Der var som sagt fælles lærerværelse, og der var fælles legeplads. I frikvartererne legede danske og tyske børn således på legepladsen - som regel hver for sig, men det kunne også ske, at nogen fandt sammen i en fælles leg og uden for skoletiden legede de naturligvis ligegodt med hinanden, om de var danske eller tyske.

Det var nemt at være gårdvagt, fordi der næsten aldrig var noget knas, undtagen når der var sne. For sneboldkampe blev altid danske mod tyske, og det var altid danskerne, der fik klø, fordi der var mange flere tyske børn end danske. Da jeg kom til Højer, var der ca. 60 børn i 


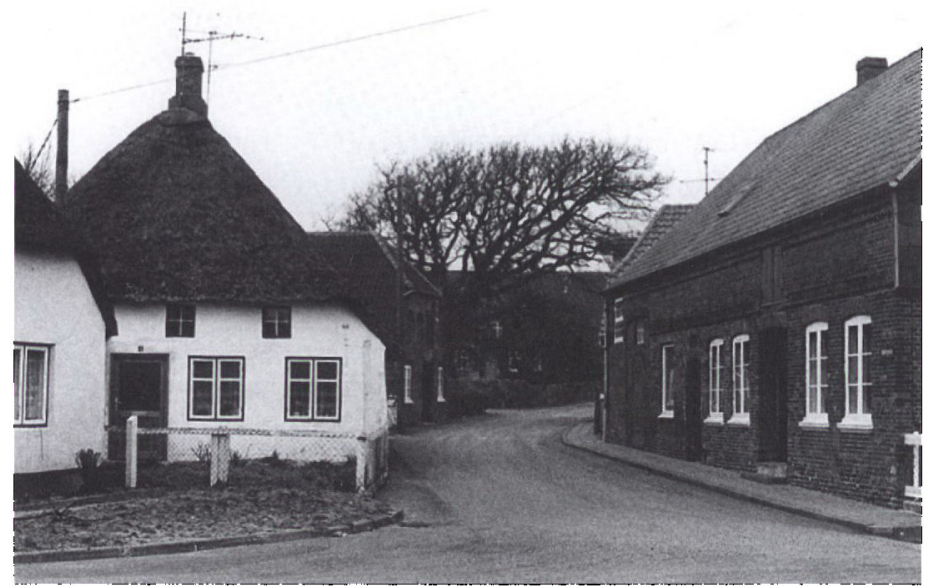

Møllegade $i$ Højer, 1975. Dette billede fra Møllegade giver et indtryk af, hoilken by Folmer Christiansen flyttede til $i$ 1939, og hvor han boede frem til sin dod $i 2011$. Foto: Karen Vium Jensen. Højeregnens Lokalhistoriske Arkiv.

den danske skole og næsten dobbelt så mange i den tyske. På lærerværelset kunne danske og tyske lærere før krigen sidde og have det meget gemytligt sammen. Smådrille hinanden kunne vi også, men vi talte aldrig om nationale forhold. Da Besættelsen kom, var det sjældent, at vi sad der samtidig. Når der skulle være indmeldelse - de første år var det altid til 1. april - $\mathrm{i}$ den danske og tyske skole, var vi altid meget interesserede $i$, om der kom flere elever i den danske skole end $i$ den tyske skole. Det var nu ikke så tit, at det hændte.

Den 9. april 1940, da den tyske hær rykkede ind i Danmark, havde vi været i Højer et år, og jeg har altid bagefter været taknemmelig for, at jeg havde lært Højer at kende før Besættelsen. Det var en mærkelig ting at opleve den tyske besættelse i en by, hvor det store flertal modtog de tyske tropper som venner, og hvor vi andre jo modtog dem som fjender. Jeg kan huske, hvordan jeg oplevede den 9. april. Om morgenen omkring klokken otte var jeg på vej til skole og mødte politibetjenten, som standsede sin bil og sagde: »Danmark er besat«. Af hvem, sagde jeg. "Af tyskerne.« Arh, det er logn. Men han kunne fortælle om træfningerne ved Bredevad og andre steder, så jeg måtte tro på, at det var sandt. Da jeg kom ned på skolen, mødte vi to danske lærere de tre tyske lærere, og som altid ønskede vi hinanden god morgen med håndtryk. Jeg tror, de tyske lærere var lige så grønne i hovederne, som vi var, men de kom nok hurtigere til sig selv. Klokken 
ti lukkede de skolen og sendte børnene hjem. Mange af børnene og deres forældre tog til Tønder for at møde tyskerne - det var længe før, der kom tyske soldater til Højer - og de tyske lærere tog også ud for at hilse på besættelsesmagten.

Så gik tiden, og vi undgik i de første krigsår at have tyske soldater på skolen. Men fra 1943 til 1945 var der hele tiden tyske soldater på skolen. Gymnastiksalen og skolekøkkenet havde de hele tiden, sommetider havde de også et klasseværelse, og så brugte de skolepladsen, dels som oplagringsplads og dels som øvelsesterræn. Det kunne godt være, at man kiggede ind $\mathrm{i}$ et kanonrør, når man stod i sin klasse og kiggede ud, fordi tyskerne holdt øvelse på skolepladsen. Man kunne jo godt blive knotten og smække vinduet op og lade børnene synge en dansk sang. Jeg skal love for, at de sang godt med. De holdt især af en norsk sang, der gik på melodien af den engelske kongesang. Så den engelske kongesang gjaldede ud over de tyske soldater, men de var nu ligeglade. Vi må sige, at soldaterne altid opførte sig pænt, men naturligvis var det ubehageligt med den uro og støj, som det gav på skolen.

$\mathrm{Nu}$ springer jeg frem til Befrielsen for lige at blive ved skolen. Den 4. maj blev for de fleste danske den største oplevelse - den største aften - $\mathrm{i}$ vores liv. Min kone og jeg var sammen med sognepræst N.P. Nielsen - det var ham, der blev til grænsepræst i 1935 - og vi havde en dejlig aften, hvor fru Nielsen stødte de kaffebønner, hun havde gemt, i en morter og lavede ren kaffe. Præsten, som ellers ikke røg, tog en cerut. Det var jo sådan, at alle tyskere, der havde været Zeitfreiwillige - altså under krigen blev der oprettet et tysk hjemmeværn, der kaldtes Zeitfreiwillige $e^{8}$ - blev interneret i Faarhuslejren. ${ }^{9}$ De blev hentet den 9. maj, og det gjorde de tyske lærere også. Jeg skammer mig stadigvæk over den nedværdigende måde, hvorpå afhentningen foregik. Derefter var der kun en tysk lærerinde tilbage på skolen - senere kom der en lærerinde mere til - og de holdt så skolen gående med nedsat timetal indtil den 27 . juni, hvorefter den tyske skole blev lukket. De tyske børn var så uden undervisning resten af året - altså uden skoleundervisning i hvert fald. I 1946 blev der oprettet nogle særklasser, hvor de tyske elever fik undervisning. Dels af danske lærere, der underviste i dansk, historie og geografi, og dels af tyske lærerinder, som underviste i de øvrige fag. Det varede kun i tre måneder, så ville vi simpelthen ikke mere. Derefter blev den tyske skole igen nedlagt, og de tyske børn var uden undervisning indtil den 7 . juni. Da kom den tyske borgmester ned til den danske førstelærer. 
Han ville gerne indmelde 71 elever fra den tyske skole i dansk skole til at begynde næste morgen, og han kom om eftermiddagen. Han havde nok håbet på, at lærer Sølvbæk, som førstelæreren hed, havde sagt, at det kan vi ikke med så kort varsel, for borgmesteren ville gerne have særklasserne oprettet igen. Men Sølvbæk sagde: »De skal være velkomne.« Derfor måtte skolens timeplan i løbet af natten laves om fra en fireklassesskole til en femklassesskole, og de 71 tyske elever fordeltes sammen med de 117 danske elever på de fem klasser. I den ældste klasse, femte klasse, var der 51 elever, og heraf var ca. halvdelen fra den tyske skole. Eleverne var indstillet på, at det skulle gå godt, og det var lærere og forældre også. Selv om det var bøvlet, så gik det faktisk - synes jeg - godt. Vi havde den store fordel, at alle de tyske elever jo havde dansk som hjemmesprog. De forstod udmærket dansk, og de var godt underviste fra den tyske skole. Kort efter lavede vi skolen om fra en femklassesskole, først til en seksklasses og senere til en syvklassesskole, og sådan blev det derefter.

I den følgende tid skød tyske privatskoler op rundt omkring i Sønderjylland. Det varede længe, inden regeringen kunne finde ud af, hvordan man skulle ordne skolevæsenet i Sønderjylland, men resultatet blev, at de tyske kommuneskoler blev nedlagt efter stor diskussion. Og så skød de tyske privatskoler op rundt omkring i landet, men det var først i 1951, at der kom en tysk privatskole i Højer. Indtil da gik de tyske elever altså i dansk skole i Højer, og nogen af dem var jo blevet konfirmeret i mellemtiden. Nogen blev så taget ud, da den tyske skole blev oprettet, og enkelte blev tilbage i den danske skole.

Som jeg sagde, har naboskabet i Højer efter min opfattelse altid været godt, selv under krigen, og der har aldrig fra tysk side været noget angiveri imod danske. En dag - det har vistnok været omkring 1943 - da vores ældste søn på fire-fem år kom hjem fra børnehave, mødte han en tysk nabokone, der venligt spurgte: »Nå, Søren, kommer du nu fra børnehave?«. Hvortil den lille laban svarede: »Hvad, er du fræk? For så skal du skydes. Min far siger, at alle tyskere skal skydes." Det har jeg vitterlig aldrig sagt, men han har nok kunnet fornemme, hvordan stemningen var i hjemmet. Men konen var så flink, at hun gik ind til min kone og fortalte historien og sagde: »Det gør ikke mig noget, men jeg tror nok, I skal være lidt forsigtige.« Min kone takkede hende hjerteligt, fordi hun havde været så venlig at komme og fortælle det.

Det har jo været sådan i Højer, at sproget egentlig altid har været dansk. Det har godt nok været sådan, at man i en vis udstrækning i de 


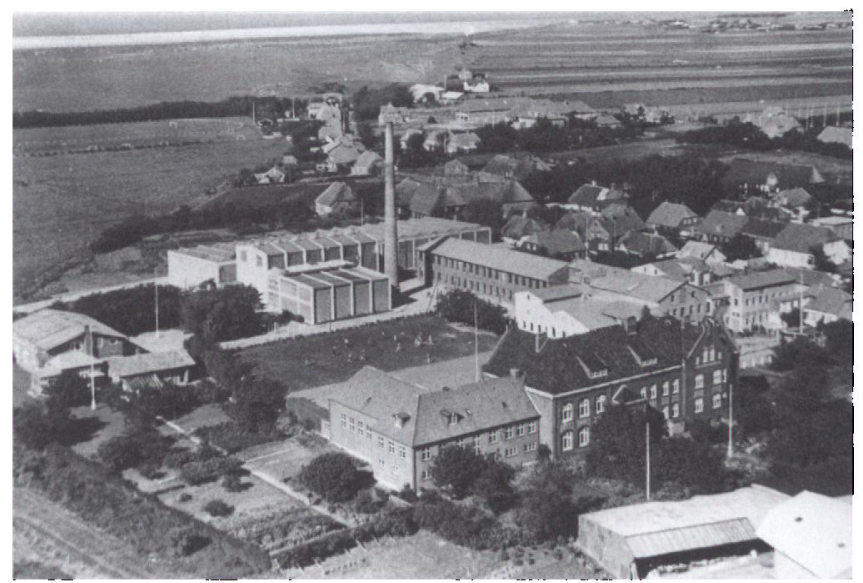

Luftfotografi med Hojer Skole i forgrunden og Sonderjysk Tappefabrik i baggrunden, ca. 1960. Folmer Christiansen var tat forbundet med Hojer Skole gennem et halvt århundrede. Forst som lærer og siden som skoleinspektor. Da han blev ansat som andenlærer $i 1939$, var der tysk skole i den sydlige del og dansk skole $i$ den nordlige del.

velhavende familier skrev på tysk, når man skrev breve. Men det er først fra omkring 1830, at folk bevidst er gået over til at være tyske, og det har mest været de velhavende, der har sluttet sig til tyskheden. Som sagt, de fleste tyske hjem havde dansk hjemmesprog, og der var mange tyskere, der fuldstændig var som danskere. De var lune jyder ligesom os andre. En tysk snedkermester var sådan en type; en lun jyde, der altid talte sønderjysk, men han var altså tysksindet. Folk, der kom hertil udefra og traf ham, kunne ikke i deres vildeste fantasi få den tanke, at han var tysk. Derfor var det sommetider, at de var lidt uforsigtige under krigen. Jeg kan huske, at jeg stod og talte med ham en dag, hvor der kom en repræsentant - det var imens, det gik løs nede på Malta under Anden Verdenskrig - og repræsentanten sagde: »Ja, nu skal jeg love for, at tyskerne får klø dernede på Malta.« Jeg kiggede på snedkeren, og han kiggede på mig, og jeg drejede samtalen hen på noget andet.

Der var en teknisk skole i Højer, og der var der både danske og tyske lærere, og det var den samme snedkermester, der var formand for skolen. En gang havde teknisk skole besøg af en ingeniør fra Grønlands Styrelse. Han skulle holde foredrag om Grønland og vise en film, og bagefter fik snedkeren, ingeniøren og jeg en kop kaffe nede på Hotel Sylt. Da spurgte ingeniøren: »Sig mig, hvordan klarer I jer her i Højer med alle de tyskere? « Han kunne ikke få den tanke, 
at snedkeren var tysk. Og jeg kiggede på Wolf og sagde: "Jo, det skal jeg sige Dem. Her sidder nu Wolf, som er tysk, og jeg, som er dansk, og vi har et udmærket samarbejde, blandt andet i teknisk skole.« Nå, så snakkede vi igen om Grønland.

Den 4. maj og de forste dage efter Befrielsen var meget kaotiske $i$ Højer. Den 4. maj blev en søn af direktør Kjærby på tæppefabrikken begravet. Den 1. maj var han blevet dræbt af noget ammunition, som tyskerne havde smidt fra sig, og som nogle drenge gik og legede med. Han blev ramt og døde og blev begravet den 4 . maj om eftermiddagen. Et par dage efter blev en gendarm, som havde været $i$ koncentrationslejr og var kommet meget syg hjem, begravet. Der var også en dansk frihedskæmper, der stammede fra Højer, men som ellers boede i Skærbæk; han var blevet dræbt af tyskerne den 5. maj, og blev begravet i Højer. Så vi gik fra befrielsesfest til begravelse og tilbage igen. Det var nogle mærkelige dage.

Som jeg nævnte, så er Højer karakteristisk ved, at danske og tyske bor imellem hinanden, og folk, der kommer hertil nordfra, vil nok efterhånden opdage, at der er en tysk skole i byen, og at der er tyske foreninger i byen. Der har været tysk børnehave - den blev nedlagt for et par år siden - og der har været tysk læge, og der er tysk kirkegang. Men ellers vil de ikke opdage, at der er noget. De vil dårligt opdage, at der er to nationaliteter sammen.

Det var svært i de tyske hjem, da mændene blev sendt til Faarhuslejren. Som jeg sagde før, skete det på en meget nedværdigende måde, og de fik også en - i mange tilfælde - for lang straf. Men at de skulle straffes, det var jeg i hvert fald helt indforstået med. For de havde sat sig ud over dansk lov, og de havde været i tysk uniform under krigen.

Hvordan har man det så med hinanden i dag? Jeg må sige, at efterhånden er det jo blevet en ren forbrødring. Altså, vi har nærmest et ideelt forhold til hinanden - dansk og tysk - men det er stadigvæk sådan, at jeg kommer ikke i den tyske skole, selv om der er et foredrag, som godt kunne interessere mig. Jeg kommer kun, når jeg bliver inviteret. Tyskerne kommer gennemgående ikke på ungdomsskolen, selv om der foregår noget, som de godt kunne være med til. Danskerne går ikke i kirke med tysk præst, selv om de fleste godt kan forstå den tyske prædiken, og tyskerne går ikke i dansk kirke, selv om de kan forstå hvert ord. Det er naturligvis mest den ældre generation, der har det på den måde. De unge mennesker går ikke op i dette her med, om det er tysk eller dansk. 
Men jeg vil foreløbig slutte med denne historie fra slutningen af 1950'erne. Henne på Strandvejen ligger der en gård, og gårdejeren var leder af den tyske byrådsgruppe, og han var samtidig vurderingsmand. Jeg havde en vurderingssag med forsamlingshuset, som jeg skulle have ordnet, og kom hen til ham en aften. Da sad der $i$ hans stue - hans kone var ikke hjemme - et søskendepar oppe fra møllen. Et tysk søskendepar. De havde en flaske tysk brændevin på bordet, og jeg blev budt til at sidde ned og få en snaps med. Vi fik ordnet denne her vurderingssag, og så fik vi en snaps mere og sad og snakkede. Så spurgte manden oppe fra møllen: "Sig mig, hvordan har dine børn det? « Jo tak, sagde jeg, de har det godt. »Ham den lange, hvad var det nu han hed, Søren, ja hvad er det blevet af ham?« Jo, han er lærer ovre på Sjælland - det var han dengang. "Hvem var det nu han blev gift med?« Og jeg vidste jo godt, at den, der spurgte, kendte min søns tyske svigerfar, som blandt venner blev kaldt »Pole«. Så jeg svarede: »Han er gift med Poles datter.« »Nå, ja så er hun jo tabt for tyskheden." Ja, sagde jeg, og det er hendes søster også. Nå, hvad da? Ja, hun er også gift med en dansk lærer. Og så rejser han sig op og glor mig olmt ind i øjnene, og så råbte han: "Ja, I æder os op I sataner.« Det var lige så arrigt ment, som det var sagt, men vi var lige gode venner for det. I 1950'erne var der altså stadigvæk den slags ting, man kunne komme ud for.

Hvilken betydning har det tyske mindretal $i$ dag - som du ser det - $i$ Højer?

Man kan dårligt sige, at tyskerne i Højer har nogen speciel betydning. Altså, de har deres egen forening - der Deutsche Nordschleswiger og det er jo stadigvæk tyskere, der sidder på jorden. Derfor har tyskerne i Højer jo altid været det stabile element. Og jeg vil tro, at der i dag er ca. en 20-25\% tyskere i Højer. Det er, som jeg siger, stabilt, men de falder fuldstændig ind i det fælles liv. Og da de, der havde været i Faarhuslejren, kom hjem, har jeg haft indtryk af, at de alle sammen uden videre gik ind i de forhold, som de havde levet under, for de kom til Faarhus. Der var ikke nogen af dem, der på nogen måde fik en dårlig modtagelse, da de kom hjem igen.

Du sagde også, at der var ganske mange mænd fra Højer, der var gået til under Forste Verdenskrig. Hvilken betydning fik det for genopbygningen $i$ Højer op gennem 1920'erne? 
Det har jeg svært ved at sige noget om, for det har jeg aldrig spekuleret i. Men det er klart, at de fleste af de 51 faldne her fra Højer var tyske, og under krigen havde de, der havde gård eller ejendom, i en lang periode fået hjælp af russiske krigsfanger, og deres bedrift blev altså holdt $\mathrm{i}$ gang. Da de kom hjem, gik de jo lige ind i den bedrift igen. Men de, der ikke kom hjem, det var som sagt flest tyske, og der var nok ikke mange af de danske, der havde jord. Det tror jeg ikke. For dette med jorden, det blev jo ellers et spørgsmål i den følgende tid. Tyskerne oprettede i 20'erne Kreditanstalt Vogelgesang, og dens opgave var at skaffe så meget jord på tyske hænder som muligt og få det båndlagt, så det forblev tysk. Det var også sådan, at hvis en dansker solgte jord til en tysker, så blev han meget ugleset. Efter at Kreditanstalt Vogelgesang var oprettet, så oprettede danskerne Landeværnet, som så sørgede for så vidt muligt at beholde dansk jord på danske hænder. Men det betød meget $\mathrm{i}$ de år derefter.

Du spurgte, hvordan det gik med genopbygningen her. I 1920 kom vi jo ind under Danmark, og derfor var det jo dansk styre, der sørgede for, at infrastrukturen kom i orden med veje og så videre. I det store hele fungerede det videre, som det havde gjort inden krigen, men andet kan jeg sådan set ikke sige om det.

Når man læser historiebøger om Sonderjylland i den nazistiske periode, kan man få indtryk af, at alle fra det tyske mindretal var nazister. Hvad er dit indtryk - hoor stor og hoordan var opbakningen blandt det tyske mindretal i Højer til den nazistiske ideologi?

Altså, så godt som alle tyske gik ind for nazismen, og der var jo også nogle af de unge tyske, som meldte sig som frivillige til værnemagten eller til SS. Og hvordan så danskerne på det? Altså, de syntes vel ikke, at det var så unaturligt, at de meldte sig til tysk krigstjeneste, når de var nazister. Men hovedsynspunktet var det, at de var godt tossede, at de gjorde det. Jeg kan nævne en ung tysker, som meldte sig til værnemagten, og da han kom hjem på orlov, holdt den tyske forening en fest på det tyske hotel. Der bad de ham om at fortælle. De havde jo håbet, at han nu ville fortælle nogle gode beretninger fra krigen, men det eneste, han sagde var: "Das ist alle Scheisse." Han har selv fortalt mig det, så jeg må gå ud fra, at det passer. 
Hvordan har synet blandt det tyske mindretal efter krigen været på perioden under den tyske besættelse og den nazistiske periode? Hvordan har man set på sin egen rolle?

Jeg tror nok, at de har fortrudt, at de gik ind i nazismen efter, at de havde set, hvad det førte til. Der var en familie Kier i Højer, der har haft den store Kiers Gaard, der nu fungerer som en slags kulturcentrum - så længe det nu varer. En søn fra Kiers Gaard fik en gård ved Jejsing. Hans søn har i mange år været $\mathrm{i}$ Tønder byråd som byrådsmedlem, Christian Kier fra Jejsing. Hans ældste bror var dansk soldat i 1940 og var med blandt dem, der blev sendt ud ved Bredevad for at tage imod de tyske tropper, når de kom ind der. Han lå $i$ vejgrøften bag et maskingevær sammen med en dansk kammerat, og han fortæller selv, at han allermest havde lyst til at springe op og løbe over til sine venner. Men han blev altså liggende der. Hans kammerat blev ramt i hovedet, og han gjorde alt muligt for at hjælpe ham. Efter at træfningen var endt, blev de danske soldater taget til fange, og nogle få dage efter blev de frigivet. Noget af det første han gjorde, da han kom hjem, var at melde sig til SS. Et år efter faldt han i Rusland. Men det har jo i mange tilfælde været forældrenes nazisme, der har bevirket, at de unge meldte sig til krigstjeneste.

Hvordan var synet - set fra dansk side - på, at der var medlemmer af det tyske mindretal, der meldte sig til tysk krigstjeneste?

Ja, som jeg sagde, så tror jeg, at det kunne man i og for sig godt forstå. Når de var nazister, så meldte de sig. Men man syntes, de var godt tossede. Nogen af dem havde jo som tyske soldater selv oplevet Første Verdenskrig, og de vidste, hvad det drejede sig om. Så de syntes, at de var tossede. Der var en gartner i byen, som var tysk, og som var en udpræget lun jyde og et af de bedste mennesker, jeg har kendt. Han syntes i løbet af krigen, at han for sin samvittigheds skyld var nødt til at melde sig til krigstjeneste, og det giorde han så. Han kom hjem - det var vel et par år efter krigen - og han sagde til mig: "Det er det dummeste jeg nogensinde har gjort. «

Uden for emnet kan jeg sige, at jeg tit kom ned til den tyske gartner for at handle, og vi fik altid en god snak. I 1972, da der var tale om, at vi skulle ind i fællesmarkedet, var han og jeg lige betænkelige ved situationen og lige usikre over for den. Men det var tyskeren, der en 
dag citerede en dansk digter: »Hvad er denne brydningstime; skumring eller gry? ${ }^{10}{ }^{10}$ Det var tyskeren, der sagde det.

\section{NOTER}

1. Informationerne $i$ forordet er primært hentet fra Steen Tygesens mindeord for Folmer Christiansen i Sonderjysk Almanak 2012, s. 169-170.

2. En epaulet er en skulderdekoration på gallauniformer.

3. Folmer Christiansens datter.

4. Troels Fink var dr. phil. i historie, og han var blandt andet dansk generalkonsul i Flensborg i mange år.

5. Johannes Kjærby efterfulgte $\sin$ far A.R. Kjærby som direktør på Sonderjysk Tæppefabrik.

6. Folmer Christiansens barnebarn og hendes mand.

7. Socialdemokratisk undervisningsminister 1924-26.
8. Der henvises til korpset af Zeitfreiwilligen, hvortil der fra begyndelsen af 1943 blev hvervet mænd fra det tyske mindretal i Sonderjylland. Korpset kan nærmest betegnes som en slags hjemmeværn.

9. Efter Befrielsen blev Froslevlejren omdøbt til Faarhuslejren, og hovedparten af de internerede fra det tyske mindretal blev indsat her.

10. Fra første vers i Jens Christian Hostrups »Det, som lysner over Vangen .

\section{Zusammenfassung}

Der Artikel mit den Erinnerungen von Folmer Christiansen ist die Abschrift eines Video-Interviews vom Herbst 2007. Es dreht sich um ein mündliches Interview fast im Stil eines Vortrages mit nur wenigen abschliessenden Fragen.

Folmer Christiansen wurde am 2. Juli 1913 geboren. Er war an der pädagogischen Hochschule in Silkeborg als Lehrer ausgebildet. Im April 1939 zog Folmer Christiansen nach Højer, wo er als Zweitlehrer an der dänischen Schule angestellt wurde. Bis zu seinem Tode am 3. Februar 2011 war er für die Stadt Højer ein halbes Jahrhundert lang vor allem als Lehrer und Schulleiter von grosser Bedeutung und war gleichzeitig in vielen anderen Zusammenhängen tätig.

Nach seiner Pensionierung engagierte er sich im Lokalhistorischen Archiv, schrieb mehrere Bücher und hielt zahlreiche Vorträge. Er war in jeder Hinsicht dänisch, was für ihn Offenheit und Respekt anderen gegenüber bedeutete. Deshalb hatte er auch, wie es aus seinen Erinnerungen hervorgeht, ein gutes Verhältnis zu seinen deutsch gesinnten Nachbarn. 